\title{
Inovasi Pelayanan Publik Pemerintah Provinsi Kepulauan Riau Di Era Revolusi Industri 4.0
}

\author{
Agus Hendrayady \\ Program Studi Administrasi Negara \\ Fakultas Ilmu Sosial dan Ilmu Politik \\ Universitas Maritim Raja Ali Haji \\ agushendrayady5873@umrah.ac.id
}

\begin{abstract}
Rapid technological developments have caused many disruptions, where this disturbance does not only appear in the private sector, but also has spread to the government sector. Thus a lot of things must be done to anticipate technological developments that have entered the new framework, namely the Industrial Revolution 4.0. In 2018, the President of the Republic of Indonesia, Joko Widodo has launched a road map "Making Indonesia 4.0". This Road Map is Indonesia's national strategy in order to face the era of the Industrial Revolution 4.0. The existence of this Road Map indirectly makes all regions in Indonesia have to prepare themselves to provide the best public services in this digital era, as well as the Government of the Riau Islands Province. Riau Islands Province, which is one of the border regions, especially with Singapore and Malaysia, will certainly feel the true Industrial Revolution 4.0 so that it must provide maximum public services. The Riau Islands Provincial Government has launched innovative products in providing public services. This article will explain about innovative public service products in the Riau Islands Provincial Government in the face of the era of the Industrial Revolution 4.0.
\end{abstract}

Keywords: Innovation, Public Service, Industrial Revolution 4.0.

\begin{abstract}
ABSTRAK
Perkembangan teknologi yang cepat banyak menyebabkan gangguan, dimana gangguan ini tidak hanya muncul pada sektor swasta atau sektor private saja, tetapi juga telah merambah sampai kepada sektor pemerintah. Dengan demikian banyak hal yang harus dilakukan guna mengantisipasi perkembangan teknologi yang telah memasuki alaf baru yaitu alaf Revolusi Industri 4.0. Tahun 2018, Presiden Republik Indonesia, Joko Widodo telah meluncurkan road map "Making Indonesia 4.0". Road Map ini merupakan strategi nasional Indonesia dalam rangka menghadapi era Revolusi Industri 4.0. Dengan adanya Road Map ini secara tidak langsung membuat seluruh daerah-daerah di Indonesia harus mempersiapkan dirinya untuk menyelenggarakan pelayanan publik yang terbaik di era serba digital ini, demikian pula halnya dengan Pemerintah Provinsi Kepulauan Riau. Provinsi Kepulauan Riau yang merupakan salah satu wilayah perbatasan terutama dengan Singapura dan Malaysia tentunya akan merasakan betul Revolusi Industri 4.0 ini sehingga harus
\end{abstract}


228 | Agus Hendrayady. Inovasi Pelayanan Publik...

memberikan pelayanan publik yang maksimal. Pemerintah Provinsi Kepulauan Riau telah meluncurkan produk-produk inovatif dalam memberikan pelayanan publik. Tulisan ini akan menjelaskan tentang produk-produk inovasi pelayanan publik di Pemerintah Provinsi Kepulauan Riau dalam menghadapi era Revolusi Industri 4.0.

Kata Kunci : Inovasi, Pelayanan Publik, Revolusi Industri 4.0.

\section{Pendahuluan}

Salah satu tugas pemerintah adalah memberikan pelayanan yang terbaik bagi masyarakat. Pelayanan pada hakekatnya adalah suatu proses untuk melakukan atau memberikan sesuatu dari satu pihak kepada pihak lain. Apabila pihak yang melaksanakan pelayanan tersebut Aparatur Sipil Negara maka dikenal dengan sebutan pelayanan publik. Pelayanan publik menurut Undang-Undang No. 25 tahun 2009 adalah Kegiatan atau rangkaian kegiatan dalam rangka pemenuhan kebutuhan pelayanan sesuai dengan peraturan perundang-undangan bagi setiap warga negara dan penduduk atas barang, jasa, dan/atau pelayanan administratif yang disediakan oleh penyelenggara pelayanan publik.

Pelayanan publik menurut Kurniawan (2016:569) merupakan suatu tolok ukur kinerja pemerintah yang paling kasat mata. Hal ini dikarenakan masyarakat dapat menilai secara langsung kinerja pemerintah dengan berdasarkan pelayanan yang mereka terima. Untuk itu, kualitas pelayanan publik di semua kementerian atau lembaga pemerintah adalah suatu hal yang paling mendasar yang harus segera ditingkatkan.

Setelah Undang-undang Nomor 25 Tahun 2009 Tentang Pelayanan Publik disahkan dan diberlakukan, penyelenggaraan pelayanan publik diamanatkan untuk terus meningkatkan kualitas dalam rangka menjamin kesederhanaan, kemudahan, keterjangkauan, dan memberikan manfaat bagi masyarakat. Apalagi dengan semakin berkembangnya kemajuan teknologi dan informasi yang mengakibatkan dunia menghadapi era revolusi industri 4.0 dewasa ini, masyarakat juga semakin memiliki kesadaran tentang hak-hak mereka sebagai warga negara yang selalu mengharapkan pelayanan yang terbaik dari aparatur pemberi pelayanan publik.

Apabila aparat pemberi pelayanan publik tidak mampu menyesuaikan diri dengan berbagai perubahan yang terjadi dalam alaf ini, maka akan tersingkir dari persaingan dan akan kehilangan simpati dan kepercayaan dari masyarakat. Agar pelayanan publik dapat lebih maksimal maka dibutuhkan inovasi dalam pengembangan pelayanan. Dengan hadirnya inovasi pelayanan sebagai suatu produk yang relatif baru tentunya akan dapat menggantikan cara-cara lama dalam pemberian pelayanan.

Inovasi dalam proses penyelenggaraan pelayanan publik pada birokrasi pemerintah menurut Mile dan Roste (dalam Marom,2015:53) terlahir karena didorong adanya motivasi- 
motivasi tertentu yaitu : carrier, idealism, self fulfilment, money (salary), prestige, professional recognition, dan potential for spin-off business. Motivasi-motivasi tersebut menurut Marom (2015:53) terjadi pada tataran individu, sedangkan pada tataran organisasi, motivasi itu tercipta untuk the propagation of policy, idea or rationality, increase funding, problem solving (in order to reach objective), more staff dan public relation.

Berbicara tentang inovasi pelayanan, Pemerintah Provinsi Kepulauan Riau juga terus mengembangkan inovasi-inovasi dalam pemberian pelayanan publik. Pengembangan inovasi pelayanan publik bagi Pemerintah Provinsi Kepulauan Riau sangat diperlukan mengingat letak wilayah provinsi ini yang berbentuk kepulauan, dimana luas daratannya hanya 4\% dibandingkan dengan luas lautannya yang mencakup hingga 96\%. Hal ini sebagaimana termuat dalam Laporan Akhir 2018 Bappelitbang Provinsi Kepulauan Riau, yaitu, "Pemerintah Provinsi Kepulauan Riau dituntut kesiapannya untuk turut serta mengembangkan sistem inovasi di daerah sebagai upaya peningkatan daya saing wilayah." (2018 : I.5). Dengan luas wilayah yang sedemikian rupa tentunya menjadi sebuah tantangan bagi Pemerintah Provinsi Kepulauan Riau untuk memberikan pelayanan publik yang maksimal bagi masyarakatnya.

Pentingnya inovasi pelayanan publik ini dapat dilihat dari beberapa penelitian yang dilakukan terhadap inovasi pelayanan publik di beberapa daerah di Indonesia. Misalnya di Lingkungan Pemerintah Daerah Kota Surabaya yang memiliki program inovatif 6 in 1, dimana program ini merupakan program di bidang pelayanan administrasi kependudukan, yaitu bagaimana masyarakat dalam mengurus keperluan pelayanan administratif mereka cukup dengan mengunggah dokumen yang dibutuhkan melalui aplikasi berbasis telepon pintar (smartphone). Dan inovasi yang kedua adalah dengan program Tahu Panas yang merupakan singkatan dari Tak Takut Kehujanan dan Tak Takut Kepanasan. Dimana program Tahu Panas ini dilakukan dengan cara melakukan perbaikan rumah tidak layak huni dan pembangunan jamban sehat melalui program rehabilitasi sosial daerah kumuh yang diintegrasikan dengan pemberdayaan ekonomi. (Wicaksono, 2018 : 202-203).

Stasiun Kereta Api Malang juga melakukan inovasi pelayanan transportasi publik berbasis teknologi informasi, yaitu program B2B (Business to Business) atau pembelian Melalui Channel External, ReservasiTiket Kereta Api H-90, CIC (Check In Center), Customer Care, Manajemen Komplain, dan Toilet Ramah Lingkungan. Keenam inovasi pelayanan transportasi publik berbasis teknologi informasi ini diberikan untuk meningkatkan pelayanan publik menjadi lebih cepat dan transparan sehinggan menjadi lebih efektif dan efisien serta mengurangi resiko terjadinya diskriminasi dalam memberikan pelayanan, ketidakpastian 
230 | Agus Hendrayady. Inovasi Pelayanan Publik...

mengenai waktu ataupun biaya pelayanan dan tentunya mengurangi pungutan liar yang sering terjadi. (Nasikhah, 2019 : 26 - 37).

Pemerintah Kota Bandung juga memiliki banyak inovasi dalam memberikan pelayanan publik dalam menghadapi era revolusi industri 4.0. seperti Dinas Penanaman Modal dan Pelayanan Terpadu Satu Pintu (DPMPTSP) dengan program HAYU, GAMPIL (Gadget Mobile Application for License). Dinas Pendidikan dengan "Si Kasep", sebuah inovasi untuk melakukan seleksi Kepala Sekolah, Dinas Kependudukan dan Pencatatan Sipil Kota Bandung dengan inovasi Mang Udin yang merupakan singkatan dari Mangga Urus Identitas Kependudukan, dan Bi Eha singkatan dari Bisa Euy Hebat. Serta inovasi Sajadah (Sampah Jadi Banda Bila Dipilah yang dilakukan oleh Kelurahan Sukaraja, Kecamatam Cicendo Kota Bandung, yaitu program di bidang lingkungan mengurangi kuantitas samapah, mengelola sampah dimulai dari rumah tangga sehingga wilayah menjadi bersih dan sejahtera karena sampah bernilai ekonomis setelah diolah. (Muharam, 2019:43).

Berdasarkan uraian pada latar belakang yang menunjukkan bahwa inovasi pelayanan publik merupakan masalah yang krusial yang harus mendapatkan perhatian terutama oleh aparatur Pemerintah Provinsi Kepulauan Riau. Demi kemudahan arah dalam penelitian maka penulis membatasi masalahnya yaitu Inovasi Pelayanan Publik Pemerintah Provinsi Kepulauan Riau Di Era Revolusi Industri 4.0

Untuk mempermudah penelitian, maka dipandang perlu untuk penulis memberikan rumusan masalahnya, sehingga jelas arah dan tujuan pembahasan masalah penelitian tersebut. Adapun perumusan masalahnya adalah : Bagaimana Inovasi Pelayanan Publik Pemerintah Provinsi Kepulauan Riau di Era Revolusi Industri 4.0.

Berdasarkan rumusan masalah tersebut, maka yang menjadi tujuan penelitian ini adalah untuk mengetahui bagaimana inovasi-inovasi pelayanan publik yang telah diluncurkan oleh Pemerintah Provinsi Kepulauan Riau dalam Menghadapi Era Revolusi Industri 4.0 sehingga pelayanan publik yang diberikan menjadi lebih memuaskan

\section{Tinjauan Pustaka}

\section{Inovasi}

Menurut Kamus Besar Bahasa Indonesia (KBBI), Inovasi adalah pemasukan atau pengenalan hal-hal baru, pembaharuan, penemuan baru yang berbeda dari yang sudah ada atau yang sudah dikenal sebelumnya.(1994:381). Dalam Wikipedia, inovasi atau Reka Baru dapat diartikan sebagai proses dan/atau hasil pengembangan pemanfaatan/mobilisasi pengetahuan, keterampilan dan pengalaman untuk menciptakan atau memperbaiki produk, 
proses, dan/atau sistem yang baru, yang memberikan nilai yang berarti atau secara signifikan. (http://id.wikipedia.org/wiki/Reka-baru). Sementara itu, menurut Peraturan Menteri Pendayagunaan Aparatur Negara dan Reformasi Birokrasi (Menpan \& RB) Republik Indonesia Nomor 30 Tahun 2014, Inovasi adalah proses kreatif penciptaan pengetahuan dalam melakukan penemuan baru yang berbeda dan/atau modifikasi dari yang sudah ada.

Ancok (2012 : 35), memberikan definisi Inovasi sebagai suatu proses memikirkan dan mengimplementasikan pemikiran tersebut, sehingga menghasilkan hal baru berbentuk produk, jasa, proses bisnis, cara baru, kebijakan, dan lain sebagainya. Sedangkan Avanti Fontana (dalam Suprapti, 2015:6) memberikan definisi Inovasi sebagai proses mengubah ide-ide kreatif menjadi produk atau metode kerja yang berguna.

Melihat dari beberapa pengertian inovasi yang telah disampaikan tersebut, maka dapat disimpulkan bahwa inovasi adalah proses kreatif dalam melakukan penemuan baru yang berbeda dari yang sudah ada. 3 (tiga) hal utama dari inovasi adalah Produk dan Jasa, Gagasan Baru, dan Upaya perbaikan melakukan penyempurnaan dan perbaikan secara terus-menerus yang dapat dirasakan manfaatnya. (Muharam dan Fitri, 2019:39)

\section{Inovasi Pelayanan Publik}

Inovasi Pelayanan Publik menurut Peraturan Menteri Pendayagunaan Aparatur Negara Dan Reformasi Birokrasi (Menpan \& RB) Republik Indonesia Nomor 5 Tahun 2019 adalah terobosan jenis pelayanan publik baik yang merupakan gagasan/ide kreatif orisinal dan/atau adaptasi/modifikasi yang memberikan manfaat bagi masyarakat, baik secara langsung maupun tidak langsung. Menurut Imanuddin, Inovasi Pelayanan Publik dikatakan sebagai inisiatif terobosan dari instansi/lembaga publik dalam upaya meningkatkan kualitas pelayanan publik. (https://rsam-bkt.sumbarprov.go.id/berita-261-inovasi-pelayanan-publikpercepatan-peningkatan-kualitas-pelayanan-publik.html.).

Berdasarkan kesimpulan dari hasil penelitian Muharam dan Fitri (2019:39), Inovasi pelayanan publik merupakan cara baru maupun ide kreati teknologi pelayanan memperbaharui, penyederhanaan, maupun menciptakan terobosan dalam aturan, prosedur, metode, pendekatan, struktur organisasi sehingga memiliki nilai baik dari segi kualitas maupun kuantitas pelayanan.

\section{Revolusi Industri 4.0}

Revolusi Industri 4.0 adalah fase keempat perjalanan sejarah revolusi industri yang sudah dimulai sejak abad ke-18. (http://www.ombudsman.go.id/pengumuman/r/artikel- 
232 | Agus Hendrayady. Inovasi Pelayanan Publik...

proyeksi-pelayanan-publik-era-4.0). Revolusi Industri 4.0 merupakan fenomena yang mengkolaborasikan teknologi cyber dan teknologi otomatisasi. Konsep penerapannya berpusat pada konsep otomatisasi yang dilakukan oleh teknologi tanpa memerlukan tenaga kerja manusia dalam proses pengaplikasiannya. (https://www.jagoanhosting.com/blog/erarevolusi-industri-4-0/). Lebih lanjut dikatakan bahwa, Hal tersebut tentunya menambah nilai efisiensi pada suatu lingkungan kerja di mana manajemen waktu dianggap sebagai sesuatu yang vital dan sangat dibutuhkan oleh para pemain industri. Selain itu, manajemen waktu yang baik secara eksponensial akan berdampak pada kualitas tenaga kerja dan biaya produksi.

Contoh konkrit yang dapat diambil dari pemanfaatan teknologi pada bidang industri adalah proses pembukuan dan produksi yang kini sudah dapat dengan mudah diakses oleh siapa saja dan kapan saja. Terlepas dari peran teknologi dalam bidang industri, manfaatnya juga bisa didapatkan oleh seluruh lapisan masyarakat. Saat ini, pengambilan dan pertukaran informasi dapat dengan mudah dilakukan kapan saja dan di mana saja melalui jaringan internet. (https://www.jagoanhosting.com/blog/era-revolusi-industri-4-0/). Contoh konkrit lainnya adalah dengan memiliki otomatisasi yang luas atas proses produksi dari pabrik fisik mereka, perusahaan dapat memilih untuk membawa pabrik mereka lebih dekat kepada pelanggan sehingga dapat memperpendek rantai pasok dan waktu pengiriman. (Fauzan, 2018:6).

\section{Metode Penelitian}

Pada penelitian ini penulis menggunakan metode riset kepustakaan. Menurut Embun (dalam Melfianora, 2019:2) penelitian kepustakaan adalah penelitian yang dilakukan hanya berdasarkan atas karya tertulis, termasuk hasil penelitian baik yang telah maupun yang belum dipublikasikan. Dalam penelitian ini penulis, menggunakan data-data sekunder dari sumber-sumber yang dijadikan objek penelitian, baik buku-buku atau literatur, media elektronik (situs internet), media online, yang ada kaitannya dengan masalah penelitian ini. Pengumpulan data dalam penelitian ini dilakukan dengan menggunakan studi kepustakaan.

\section{Pembahasan.}

Kementerian Pendayagunaan Aparatur Negara dan Reformasi Birokrasi (KemenPAN RB) menerapkan kebijakan tentang peningkatan pelayanan publik dengan menyatakan bahwa sejak tahun 2014 adalah tahun inovasi pelayanan publik. Inovasi pelayanan publik 
ini harus diterapkan di seluruh instansi pemerintah, baik di tingkat pusat maupun tingkat daerah. Dan masing-masing instansi pemerintah diharapkan dapat membuat ide-ide kreatif atau jawaban terhadap kerja atau metode tentang pelayanan publik. Sudah banyak inovasi-inovasi pelayanan publik yang sudah dibuat oleh instansi pemerintah di tingkat pusat maupun di tingkat daerah, bahkan setiap tahun selalu ada kompetisi inovasi pelayanan publik yang diselenggarakan oleh KemenPAN RB seperti Top 99 Pelayanan Publik sehingga kompetisi tingkat internasional yang diselenggarakan oleh Perserikatan Bangsa-Bangsa (PBB) yang dikenal dengan United Nation Public Services Award (UNPSA). (Kurniawan, 2016:580).

Pemerintah Provinsi Kepulauan Riau memiliki beberapa inovasi-inovasi pelayanan publik yang berkaitan dengan era revolusi industri 4.0. Aplikasi Video Conference, dimana aplikasi ini dapat dimanfaatkan oleh Gubernur, Wakil Gubernur, Sekretaris Daerah serta para Organisasi Perangkat Daerah (OPD) di lingkungan Pemerintah Provinsi Kepulauan Riau untuk berhubungan dengan masyarakat. Artinya bahwa jika masyarakat di daerah menemukan kendala, tidak perlu jauh-jauh ke Pemerintah Provinsi, tetapi bisa melalui Kepri Tele Conference ini.

Pada saat yang bersamaan, Pemerintah Provinsi Kepulauan Riau juga meluncurkan Aplikasi SIMANJA (Sistem Informasi Manajemen Kinerja). Aplikasi SIMANJA digunakan untuk menghitung tunjangan kinerja pegawai negeri sipil (PNS) di lingkungan Pemprov Kepri. Aplikasi ini merupakan alat dan sarana yang sangat penting dalam pelaksanaan evaluasi kinerja bagi pegawai. Hal ini sangat diperlukan karena situasi pemerintah saat ini semakin menuntut setiap instansi dan lembaga untuk lebih bertanggungjawab dalam pengelolaan anggaran dan menjalankan seluruh program kerja secara lebih efektif dan efisien. Oleh karena itu, PNS diharuskan untuk mengunggah pekerjaan yang mereka setiap hari ke aplikasi SIMANJA ini. Menurut Kabid Teknologi Informasi dan Komunikasi Dinas Kominfo Provinsi Kepri, Muhammad Yunus, "Kalau pekerjaan sehari-hari diunggah, tidak sampai satu menit sudah selesai, selama jaringan internet baik." (https://www.batamnews.co.id/berita-44007-pemprov-kepri-segera-luncurkan-aplikasisimanja-apa-itu.html).

Aplikasi SIMANJA ini juga terintegrasi dengan Aplikasi SILAT (Sistem Informasi Layanan Aparatur Terpadu dan Aplikasi E-Disiplin yang dimiliki oleh Badan Kepegawaian dan Pengembangan Sumber Daya Manusia (BKPSDM) Pemerintah Provinsi Kepulauan Riau. Aplikasi SILAT ini diadopsi dari layanan e-Master BKD Jawa Timur yang mencoba melakukan perubahan pelayanan kepegawaian secara tersistematis dan terpadu. 
234 | Agus Hendrayady. Inovasi Pelayanan Publik...

Harapannya agar terjadi perubahan paradigma dalam sistem pelayanan kepegawaian. Bukan lagi pegawai bertemu pegawai, tetapi pegawai bertemu sistem. Pergeseran paradigma ini diklaim akan memaksimalkan pelayanan kepegawaian meskipun dengan tenaga yang minimal.

Aplikasi SILAT ini bertujuan sebagai upaya transformasi layanan kepegawaian. Jika selama ini pembaruan data pegawai lebih banyak diserahkan ke BKPSDM dan operator di tiap-tiap OPD, maka aplikasi SILAT adalah kebalikannya. Pegawai dituntut untuk melakukan pembaruan data pribadinya oleh diri si pegawai sendiri. Mulai dari identitas diri dan keluarga, riwayat pendidikan, riwayat kepangkatan, riwayat jabatan, riwayat diklat, dan informasi lain yang menunjang disertai dokumen asli yang telah di scan.

Aplikasi lain yang dimiliki oleh BKPSDM Provinsi Kepulauan Riau adalah E-Disiplin. Aplikasi ini digunakan untuk untuk mengetahui kehadiran pegawai di Pemprov Kepri. Bahkan Gubernur Kepri, Dr. H. Nurdin Basirun, S.Sos., M.Si., mengusulkan agar dibuat layar informasi di Gedung A Kantor Gubernur yang akan memuat jumlah pegawai yang masuk, izin, dinas, ataupun yang tanpa keterangan sama sekali. (bpsdm.kepriprov.go.id/ web/index.php/publikasi-1/artikel/413-gubernur-kepulauan-apresiasi-aplikasi-e-disiplinbkpsdm.html

Untuk meningkatkan layanan berbasis teknologi, Kantor Dinas Komunikasi dan Informasi (Kominfo) Provinsi Kepulauan Riau memiliki KIIS (Kepri Integrated Information System). KIIS ini merupakan dashboard yang mengintegrasikan penyajian informasi dan pelaporan atas pengelolaan pemerintah Provinsi Kepulauan Riau yang menggunakan sistem aplikasi dengan fungsi sesuai dengan tugas pokok dan fungsi masing-masing organisasi perangkat daerah (OPD) pelaksana. Aplikasi ini menjadi pintu gerbang informasi terkait tata kelola perencanaan pembangunan, tata kelola belanja dan pendapatan, belanja barang dan jasa, dan lain-lain.

Aplikasi lain yang dimiliki oleh Kominfo adalah Kepri Smart Province (KSP), yaitu suatu aplikasi yang lebih memudahkan bagi masyarakat yang ingin mendapatkan data seputar Kepri tanpa perlu melewati sistem administrasi yang selama ini terkesan berbelitbelit dengan hanya mengakses melalui media internet. Nasikhah (2019:26) menyatakan bahwa teknologi informasi dapat dimanfaatkan untuk meningkatkan pelayanan menjadi lebih cepat dan transparan sehingga pelayanan publik menjadi lebih efektif dan efisien. Pelayanan publik berbasis teknologi informasi perlu diterapkan untuk mengurangi resiko terjadinya diskriminasi dalam memberikan pelayanan, ketidakpastian mengenai waktu ataupun biaya pelayanan dan tentunya mengurangi pungutan liar yang sering terjadi. 
Keberadaan KSP sendiri merupakan bentuk komitmen dari Pemerintah Provinsi Kepri dalam hal menjalankan fungsi pelayanan publik berbasis elektronik. Di zaman yang semakin modern dan canggih ini kita tentunya harus terus mengikuti perkembangan zaman, apalagi tuntutan masyarakat juga dari hari ke hari semakin kompleks, sehingga dengan aplikasi berbasis teknologi ini tentunya mampu menjawab semua apa yang menjadi kebutuhan masyarakat. Gedung KSP ini menyediakan akses yang memudahkan bagi publik untuk mendapatkan data. Didalam gedung juga disediakan Kepri Smart Conference, Kepri Digital Exhibition serta ruang meeting.

Sekretariat Dewan (Sekwan) Dewan Perwakilan Rakyat Daerah (DPRD) Provinsi Kepulauan Riau juga memiliki aplikasi sendiri, yaitu SIAPEK (Sistem Akuntabilitas Pertanggungjawaban Keuangan). Aplikasi SIAPEK dibuat dalam rangka menjawab tuntutan era reformasi yang menuntut setiap pemerintahan yang terbuka dan dapat akuntabel. Aplikasi SIAPEK ini dibuat dengan asumsi dapat sejalan dengan misi Provinsi Kepulauan Riau tahun 2016 - 2021, yaitu mengembangkan tata kelola pemerintahan yang bersih, akuntabel, aparatur birokrasi yang profesional, disiplin dengan etos kerja tinggi serta penyelenggaraan pelayanan publik yang berkualitas. Oleh karena itu, aplikasi SIAPEK ini diharapkan dapat menjadi acuan dalam pengelolaan keuangan yang akuntabel, transparan, dan lebih optimal, dengan sendirinya akan membuat sistem pelaporan keuangan di DPRD Kepri dapat lebih cepat, dan akuntabel.

Harapan Sekretaris Daerah Provinsi Kepulauan Riau, Dr. H. TS. Arif Fadillah, S.Sos., M.Si, agar aplikasi SIAPEK dapat diintegrasikan disetiap organisasi perangkat daerah (OPD) sebagai sistem pengelolaan pertanggungjawaban keuangan. (https://kepriprov.go.id/home/berita/1447). Selama ini yang sering terjadi adalah keterlambatan pelaporan anggaran. Menurut Sekretaris Dewan Perwakilan Rakyat Daerah Provinsi Kepri, Hamidi, hal ini disebabkan oleh keterbatasan SDM, dan tingginya aktifitas Dewan, sehingga terkadang batas waktu penyelesaian pertanggungjawaban menjadi lambat. (https://kepriprov.go.id/home/berita/1447). Sehingga denga adanya Aplikasi SIAPEK ini dapat menjadi jawaban dari masalah-masalah tersebut.

Biro Administrasi dan Layanan Pengadaan Sekretariat Daerah Pemprov Kepri memiliki aplikasi KERIS BAJA yaitu Sistem Informasi Pengadaan Barang dan Jasa. Aplikasi ini diharapkan dapat diimplementasikan oleh setiap organisasi perangkat daerah (OPD) dilingkungan Pemprov Kepri khususnya untuk pengadaan barang dan jasa. Adapun tujuan aplikasi KERIS BAJA ini adalah dapat mempermudah dan mempercepat sistem kerja badan pengadaan barang dan jasa di Provinsi Kepri. Disamping itu juga diharapkan 
236 | Agus Hendrayady. Inovasi Pelayanan Publik...

aplikasi KERIS BAJA dapat melibatkan langsung masyarakat serta instansi lain untuk mendapatkan informasi tentang layanan pengadaan barang dan jasa di Pemprov Kepri dengan jelas, lengkap, juga transparan.

Kepala Biro Administrasi dan Layanan Pengadaan Barang dan Jasa Pemprov Kepri, Misbardi mengatakan bahwa, "Aplikasi KERIS BAJA diharapkan menjadi aplikasi yang dapat menghimpun semua sistem pengadaan barang dan jasa yang ada di Pemprov Kepri. Sehingga dapat memudahkan pekerjaan dan transparansi data yang akurat serta mampu dipertanggungjawabkan dengan baik. Sehingga kedepannya pengadaan barang dan jasa di Biro Administrasi dan Layanan Pengadaan Barang dan Jasa Pemprov Kepri dapat berjalan lebih baik, efisien, serta transparan. (https://kepriprov.go.id/home/ berita/1544).

\section{Kesimpulan Dan Saran}

Berdasarkan hasil pembahasan pada penelitian ini, maka dapat penulis simpulkan sebagai berikut :

a. Inovasi pelayanan publik dimasa revolusi industri 4.0 merupakan hal yang sangat perlu dilakukan demi peningkatan kualitas maupun kuantitas pelayanan bagi masyarakat.

b. Adapun bentuk-bentuk inovasi pelayanan publik yang telah dilakukan oleh Pemerintah Provinsi Kepulauan Riau adalah Video Conference, SIMANJA (Sistem Informasi Manajemen Kinerja), SILAT (Sistem Informasi Layanan Aparatur Terpadu), E-Disiplin, KIIS (Kepri Integrated Information System), KSP (Kepri Smart Province), SIAPEK (Sistem Akuntabilitas Pertanggungjawaban Keuangan), dan KERIS BAJA (Sistem Informasi Pengadaan Barang dan Jasa).

\section{Saran}

Adapun saran dari penelitian ini adalah sebagai berikut :

1. Beberapa aplikasi inovasi pelayanan publik perlu disosialisasikan kepada masyarakat sehingga masyarakat terutama yang berada di beranda terdepan Provinsi Kepulauan Riau dapat mengetahui bentuk-bentuk inovasi pelayanan publik yang telah dikembangkan.

2. Bentuk-bentuk inovasi pelayanan publik ini harus terus dikembangkan terutama bagi Organisasi Perangkat Daerah (OPD) yang berada di bawah naungan Provinsi Kepulauan Riau, sehingga masyarakat dapat menikmati pelayanan publik sebagaimana yang mereka harapkan dan mereka impikan selama ini 


\section{DAFTAR PUSTAKA}

\section{Buku-buku}

Ancok, Djamaludin, 2012, Psikologi Kepemimpinan dan Inovasi, Erlangga, Jakarta.

Suprapti, Wahyu, 2015, Inovasi Publik, Bahan Ajar Diklat Kepemimpinan Tingkat III, Lembaga Administrasi Negara Republik Indonesia, Jakarta.

Tim Penyusun Kamus Pusat Pembinaan dan Pengembangan Bahasa Departemen Pendidikan dan Kebudayaan, 1994, Kamus Besar Bahasa Indonesia, Edisi Kedua, Balai Pustaka, Jakarta.

Tim Penyusun Laporan Akhir 2018, Laporan Akhir Pengembangan dan Penguatan Sistem Inovasi Daerah (SIDa) Provinsi Kepulauan Riau Tahun 2018 - 2021.

\section{Jurnal-Jurnal}

Fauzan, Rahman, "Karakteristik Model dan Analisa Peluang-Tantangan Industri 4.0.", Phasti : Jurnal Teknik Informatika Politeknik Hasnur, April 2018: Volume 04, Nomor 1.

Kurniawan, Robi Cahyadi, "Inovasi Kualitas Pelyanan Publik Pemerintah Daerah.", Fiat Justisia, July-September 2016: Volume 10, Issue 3.

Marom, Aufarul, "Inovasi Birokrasi Pelayanan Publik Bidang Sosial Tenaga Kerja dan Transmigrasi di Kabupaten Kudus.", Gema Publica : Jurnal Manajemen dan Kebijakan Publik, Oktober 2015: Volume 1, Nomor 1.

Muharam, Riki Satia, dan Fitri Melawati, "Inovasi Pelayanan Publik dalam Menghadapi Era Revolusi Industri 4.0 di Kota Bandung.", Maret 2019, Volume 1, Nomor 1.

Nasikhah, Mar Atun, "Inovasi Pelayanan Transportasi Publik Berbasis Teknologi Informasi.", JISoP : Jurnal Inovasi IImu Sosial dan Politik, April 2019, Volume 1, Nomor 1.

Wicaksono, Kristian Widya, "Tipologi Inovasi Sektor Publik Pada Tiga Program Inovatif Pemerintah Daerah Kota Surabaya (Tinjauan Reflektif Terhadap Tiga Inovasi Pelayanan Publik Pemerintah Kota Surabaya Tahun 2018).", Jurnal Manajemen Pelayanan Publik, Volume 1, Nomor 2 Tahun 2018.

\section{Data Internet}

Bkpsdm.kepriprov.go.id/web/index.php/publikasi-1/artikel/413-gubernur-kepulauanapresiasi-aplikasi-e-disiplin-bkpsdm.html. Diakses pada tanggal 15 Mei 2019. http://id.wikipedia.org/wiki/Reka-baru. Diakses pada tanggal 15 Mei 2019. 
238 | Agus Hendrayady. Inovasi Pelayanan Publik...

https://kepriprov.go.id/home/berita/1447. Diakses pada tanggal 16 Mei 2019. https://kepriprov.go.id/home/berita/1544. Diakses pada tanggal 16 Mei 2019.

https://temukanpengertian.blogspot.com/2013/09/pengertian-inovasi.html. Diakses pada tanggal 15 Mei 2019.

https://www.batamnews.co.id/berita-44007-pemprov-kepri-segera-luncurkan-aplikasisimanja-apa-itu.html). Diakses pada tanggal 16 Mei 2019.

http://www.ombudsman.go.id/pengumuman/r/artikel-proyeksi-pelayanan-publik-era-4.0. Diakses pada tanggal 10 Mei 2019.

https://www.jagoanhosting.com/blog/era-revolusi-industri-4-0/. Diakses pada tanggal 06 Februari 2020.

Imanuddin, Muhammad, https://rsam-bkt.sumbarprov.go.id/berita-261-inovasi-pelayananpublik-percepatan-peningkatan-kualitas-pelayanan-publik.html. Diakses pada tanggal 17 Mei 2019.

Melfianora, https://osf.io>download, file:///C:/User?Download/KTI\%20dengan\%Literatur\% 20(1).pdf. Diakses pada tanggal 15 Mei 2019.

\section{Peraturan Perundang-undangan}

Undang-Undang Republik Indonesia Nomor 25 Tahun 2009 Tentang Pelayanan Publik.

Peraturan Menteri Pendayagunaan Aparatur Negara dan Reformasi Birokrasi Republik Indonesia Nomor 30 Tahun 2014 tentang Pedoman Inovasi Pelayanan Publik.

Peraturan Menteri Pendayagunaan Aparatur Negara dan Reformasi Birokrasi Republik Indonesia Nomor 5 Tahun 2019 tentang Kompetisi Inovasi Pelayanan Publik di Lingkungan Kementerian/Lembaga, Pemerintah Daerah, Badan Usaha Milik Negara, Dan Badan Usaha Milik Daerah. 